\title{
Casanas, Hidalgo, and Espinosa: A Spanish Leaming Curve
}

\author{
Mariah F. Wade \\ University of Texas at Austin
}

Follow this and additional works at: https://scholarworks.sfasu.edu/ita

Part of the American Material Culture Commons, Archaeological Anthropology Commons, Environmental Studies Commons, Other American Studies Commons, Other Arts and Humanities Commons, Other History of Art, Architecture, and Archaeology Commons, and the United States History Commons

Tell us how this article helped you.

This Article is brought to you for free and open access by the Center for Regional Heritage Research at SFA ScholarWorks. It has been accepted for inclusion in Index of Texas Archaeology: Open Access Gray Literature from the Lone Star State by an authorized editor of SFA ScholarWorks. For more information, please contact cdsscholarworks@sfasu.edu. 


\section{Casanas, Hidalgo, and Espinosa: A Spanish Leaming Curve \\ Creative Commons License \\ (c) $($ ) $(9)$}

This work is licensed under a Creative Commons Attribution-NonCommercial 4.0 International License 


\title{
Casañas, Hidalgo, and Espinosa: A Spanish Learning Curve
}

\author{
Mariah F. Wade \\ The University of Texas at Austin
}

In 1690, Alonso de León arrived in East Texas to establish two missions among the Asinai. He was accompanied by Fr. Fontcuberta, Fr. Casañas, Fr. Bordoy, Fr. Massanet, and Brother Antonio. Fr. Massanet returned to Mexico to inform the Viceroy about the trip, and came back to East Texas with Terán de Los Rios in August 1691. Fr. Fontcuberta died in February 1691 of an epidemic that, according to Fr. Casañas, killed about 3,000 natives in the area. Fr. Casañas who died in New Mexico in 1696, left us the first intimate view of the Caddoan-speaking groups in East Texas. Casañas Relación was written in spurts and delivered to Terán de los Rios in August 1691. The Terán expedition brought to the Asinai Fr. Hidalgo who stayed about two years. In 1716, Fr. Hidalgo returned to Texas with Fr. Espinosa. While in the Asinai Province, the social conditions, the environment for learning and the interests of the three friars were quite different. We have found little archival material from Hidalgo, and Espinosa s style and education provide a disengaged narrative that loses flavor and re-uses some of the material provided by the other friars.

The arrival of the Spaniards did not match native expectations. The Asinai wanted a Spanish community composed of families that would live side-by-side with them and would provide a measure of protection and prestige, as well as trade opportunities. Instead they got seven single males: four friars and three soldiers. Casañas grappled with a new language and its dialects, unfamiliar social and religious practices, a major epidemic in 1691 that deeply affected the relationship between Europeans and Natives, and very poor harvests in 1691 and 1692. His Relación, which serves as a colonial baseline, was created while learning, attempting to proselytize and surviving. Casañas Relación is constructed from several kinds of knowledge: what he saw, experienced, and was told.

Casañas did not travel beyond the Asinai Province, nor could he: most of the time there were only two other friars and three soldiers, and between February and August 1691 Casañas was left with one companion and two soldiers. At first, Casañas was at Mission San Francisco de los Tejas because he only established Mission Santisimo Nombre de Maria (hereafter shown as S.N. de Maria) in October 1690. From 1690 through 1691 he probably remained at S. N. de Maria where he was met by Terán on August 4, 1691. Unlike Hidalgo and Espinosa, most of the information related by Casañas concerns the political and religious structure and the practices of the people in the Asinai Province. In this article I will concentrate on two issues: first, what can we learn about the location of the nations belonging to the Asinai Province using the archival materials from these friars, and second what cosmological and religious changes occurred between the period of Casañas and Hidalgo, and the period of Hidalgo and Espinosa. I should add that all the evidence to be presented, except for obvious exceptions, is based completely on the archival materials mentioned.

\section{Location of the groups in the Asinai Province}

Casañas reports that the territory of the Province was about 91 miles to the north and east, making the Sabine River its rough eastern boundary. He provides a description of the location of the Asinai groups as he walked and rode a mule from village to village following defined traveling paths. Mission S. Francisco was 
located at the western edge of the Province seven miles west of Mission S. N. de Maria, which was located on the western margin of the Neches River. Casañas is rather specific about that, and he would not mistake a creek for a river since he points to the existence of some 30 creeks. Fr. Casañas who remained in the area for 18 months, located the following groups: Nabedacho, Nabiti, Nacachau, Nacogdoches, Nacono, Nasoni, Nechavi, Neche and Cache.

\section{Political-Religious structure-Responsibilities and Privileges}

Casañas provides a clear picture of the political-religious structure of these groups. The unifying element between the groups of the province was the Xinesi as the high priest, who never left the area, kept the sacred fire, and was the principal intermediary between the people and the spiritual world. This bounded existence of the Xinesi was a restriction of his office and has cosmological implications. The hierarchical structure had a top/down orientation balanced by horizontal structural elements. The Caddi accumulated civic and religious functions, and each Asinai division had one. At a similar hierarchical level was the Council of Elders (apparently 12), an advisory body to the Xinesi and the Caddi also responsible for civic and religious duties. If Casañas did not make a mistake in his pronouns, the Council of Elders included older women. The Canaha had civic and enforcement roles as lieutenants to the Caddi and the Elders, and they were also in charge of the lodging arrangements for the Caddi when he left the pueblo to hunt or to make war. The number of Canaha was proportional to the population, and Casañas states that while the small divisions had three or four Canaha, larger ones had seven or eight. This means that some divisions were twice as big as others in terms of population. The Chaya appeared to be lieutenants to the Canaha, and the Tarima, or Tamma, held roles as town criers and enforcers of work schedules. There were individuals who presided over burial ceremonies, but Casañas does not name them. There are substantial differences between the role assignments according to Casañas and according to Espinosa, but these differences are too numerous to be addressed in this article. However, these differences may be due to Espinosa s tendency to generalize, or to major cosmological and social shifts that occurred between the end of the 17 th century and the beginning of the 18 th century.

Between 1690 and 1693 the cosmological beliefs of the Asinai Province included two children, the Coninisi, who came from the other side of the heavens and were the intermediaries used by the Xinesi to access their Supreme Being, the Ayo Caddi Aymay. The children, who Espinosa refers to as boys and I believe to be the Twins of the Gemini constellation, had to be provided for by the people, but were cared for only by the Xinesi. Casañas, intrigued by the mystery of the children and determined to snub the superstition, asked to see the children. He was permitted access to the house, but he was told that he could not see them because "they could only be seen when they had just arrived from the other side of the sky," and that the time and an hour of their appearance coincided with the time when their house was set on fire and they were burned with it. These Twins, the Coninisi, had a physical reality translated into statues, dwelling, ritual paraphernalia, and food requirements. Some of the requests made by the Asinai to the Supreme Being via the Coninisi, related to forgiveness for failure to give appropriate amounts of harvest products. This emphasized that the gifts were never equal in value and therefore inequality in reciprocity was maintained. They also requested health, endurance, energy, victories against enemies and many women to procreate. During the first period Hidalgo was among the Asinai (1691 through October 1693), the Coninisi were still present and the Xinesi consulted then and accessed the Superior Being through them.

The third distinct part of the Relación was written after the death of Fr. Fontcuberta on February 5 th, 1691, and it was after that time that Casañas confronted the Xinesi over the children. As it happens, the Gemini constellation, The Twins, is best seen in February, and Casanas was told he could not see the Coninisi because they were only visible when they first arrived. 
Most of Espinosa s material on the Asinai resulted from his experiences between 1716 and 1719 . In October 1719, the friars abandoned East Texas. Espinosa later returned with the Aguayo expedition and recorded some material between 1721 and 1722 . Espinosa states that, sometime shortly prior to 1714, the houses of the Coninisi burned down and they saw the Coninisi climb on the smoke to the sky. This is consistent with previous statements made by the Xinesi to Casañas. What is different is that Espinosa states that since that event the Coninisi were not seen again. Unlike Casañas, Espinosa states that there were two Coninisi houses where the small coffers with sacred objects related to the Coninisi rituals were kept. Espinosa provides two scenarios for the disappearance of the Coninisi. First he implies that the destruction of the house was due to a Christian God s intervention which prepared the way for the return of the friars to the Asinai Province. Second he reports that, according to the female Asinai interpreter who had been raised in Coahuila, the destruction of the house resulted from an attack by the Yojuane on the Asinai which occurred presumably ca. 1714. Regardless, between 1691 and 1714 some drastic changes occurred in the cosmological and religious world of the people in the Asinai Province. These changes had to affect the power structure, particularly in terms of the Xinesi s access to the Superior Being.

Espinosa also states that some of the shamans, which he calls Santones, were experts in astrology and that in the month of February, called sacabbi, the Asinai groups held a large feast that involved the whole Province. During this feast, marked by propitiatory rites, drinking of laurel tea, dancing and eating, the shamans used the feathers of an eagle that ascended to the sky to communicate with the Supreme Being and serve as intermediary to the spiritual realm for weather and crop forecasts. The abundance of shaman practitioners related by Espinosa, and the use of the eagle as mediator, are absent from the Casañas report. In September, the whole Province, and possibly groups from other Provinces, celebrated a feast called sanata. This feast, which was said to be a celebration for women of all ages, began when the Pleiades were located above the house of the Xinesi and the celebration was centered on the arrival of the seven sisters in the sky.

Between 1693 and 1714 either the Xinesi or the most influential Caddi died. Whether this death was connected with the disappearance of the Coninisi is not known. In 1714 the Asinai lost their corn crop, and in June 1714 four Frenchmen, including Louis de Saint-Denis, and six Asinai came to the Rio Grande to request the friars return to their lands. One of the Asinai was Bernardino, a Caddi, and another was a person who had come to the Rio Grande some years before looking for Fr. Hidalgo. With the arrival of the Spanish in July 1716 several Caddi were appointed by the Spanish, but Bernardino remained in power. In December 1716, about six months after the return of the Spanish, the house of the Xinesi was moved and rebuilt.

To conclude, the collected archival evidence points quite strongly to the identity of the Coninisi as Castor and Polux in the constellation Gemini. The February festival would be connected to the maximum visibility of the constellation. Between 1690 and 1714 it appears that the Coninisi ascended to the sky severing their connection with the earthly realm. If that is the case, the Xinesi retained his connection to the ancestral world and the community through the Sacred Fire, but lost access to the Supreme Being through the Coninisi.

The arrival of the Spanish did not herald auspicious times. Crop failures, epidemics with consequent loss of population and inherent social disruption together with the disappearance of the Coninisi would have provoked serious structural and power changes that would affect the whole Province. To understand and gauge the cosmological and cultural changes that may have occurred during the early tenure of Casañas and Hidalgo and during the following period, we must continue to do close readings of the archival material, and scrutinize the archeological record for any clues that may substantiate these changes. 